Originalien

Z Rheumatol 2022 $81: 247-252$

https://doi.org/10.1007/s00393-021-00989-2

Accepted: 25 February 2021

Published online: 29 March 2021

(c) Springer Medizin Verlag GmbH, ein Teil von Springer Nature 2021

\section{Redaktion}

U. Müller-Ladner, Bad Nauheim

U. Lange, Bad Nauheim

\section{Supplementary Information}

The online version of this article (https://doi. org/10.1007/s00393-021-00989-2) includes Table 1. Article and supplementary material are available at www.springermedizin.de. Please enter the title of the article in the search field, the supplementary material can be found under "Ergänzende Inhalte".

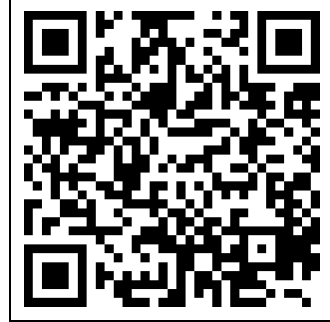

\section{Introduction}

Musculoskeletal disorders are the leading cause of years lived with disability and the fifth most common cause of disability-adjusted life years worldwide in 2017 according to estimates from the Global Burden of Diseases [1-3]. Musculoskeletal disorders cause pain and functional disability [4-6], and their burden on individuals and society has been increasing worldwide [2, 3, 7]. Therefore, public interest in musculoskeletal disorders during the coronavirus disease 2019 (COVID-19) pandemic should be assessed to develop effective measures for the management of musculoskeletal disorders.

Within the rheumatology community, Google search data have been integrated into research $[8,9]$. In the past few

Sinan Kardeş (D) - Anıl Erdem (ID · Hatice Gürdal $(\mathbb{D}$

Department of Medical Ecology and Hydroclimatology, Istanbul Faculty of Medicine, Istanbul University, Fatih/Istanbul, Turkey

\title{
Public interest in musculoskeletal symptoms and disorders during the COVID-19 pandemic
}

\section{Infodemiology study}

years, it was used to assess trends in several rheumatic and musculoskeletal diseases such as osteoarthritis [10], fibromyalgia [11], gout [12], ankylosing spondylitis [13], and rheumatoid arthritis [14]. In the context of the ongoing COVID-19 pandemic, in two intriguing studies we evaluated the public interest in anti-rheumatic drugs [15] and rheumatic diseases [16]. In the previous study, we mainly focused on inflammatory, autoimmune, connective tissue/ vasculitis diseases because patients with this group of rheumatic diseases may be at a higher risk of acquiring severe acute respiratory syndrome coronavirus 2 (SARSCoV-2) [16]. As the prevalence of soft tissue, regional and degenerative musculoskeletal diseases is much higher than the other rheumatic diseases (i.e. inflammatory, autoimmune, connective tissue/ vasculitis), the public interest in these musculoskeletal disorders also needs to be investigated.

The present study aimed to assess the public interest in musculoskeletal symptoms and disorders during the COVID-19 pandemic. It is essential for clinicians to understand the modifications and trends in public responses in looking for information about musculoskeletal symptoms and disorders, and to determine the informational needs of public during the COVID-19 pandemic. This information will help rheumatologists develop effective strategies in order to deliver better care for people with musculoskeletal disorders during the pandemic.

\section{Methods}

\section{Google search data}

The Google Trends tool can provide data on search queries users enter into the Google search engine. It normalizes the data to all queries in a region and a timeframe selected and presents the relative popularity of search queries [17-19]. Then, Google Trends scales the resulting numbers ranging from 0 to 100 based on selected search query's frequency to overall frequency of search queries. This scaling process allows the relative search volume between years to be compared, because otherwise the later years' searches would be higher than those of the earlier years due to the increase in internet use over the years. In other words, this process controls the possible impact of total amount of internet use over time. On this scale, 100 indicates the maximum popularity for the search query, and others indicate a percentage of it. For example, a score of 60 indicates a $60 \%$ of the maximum popularity for the search query $[20,21]$. We determined a broad spectrum of search queries corresponding to general musculoskeletal symptoms (e.g. fatigue, joint pain, joint stiffness, and joint swelling), and spinal, shoulder, elbow, wrist, hand, hip, knee, ankle, and foot symptoms/disorders. The whole list of 118 search queries is provided in Table 1 (Electronic Supplementary Material online). We searched Google Trends for the search queries within 
the United States, with a timeframe of January 1, 2016 to November 22, 2020, and in "All categories".

\section{Statistical methods}

To assess both initial and short-term public interest we compared two timeframes in 2020 (March 15-July 4 and July 5-October 31) to similar timeframes over the four prior years from 2016 through 2019 with the use of the generalized estimating equations selecting a gamma model. The threshold for statistical significance was considered as a P value smaller than 0.05. The statistical analyses were conducted on SPSS (version 21.0; IBM Corporation, Armonk, NY, USA). Recently published review guided the statistical data presentation [22].

\section{Results}

Analysis of the initial timeframe, March 15-July 4, revealed a statistically significant decrease in Google search volume of 71 among 118 queries and a statistically significant increase in Google search volume of 2 queries (i.e. myalgia [\% change: $+87.55 \% ; p<0.001$ ] and toe swelling [+16.96\%; $p$ : 0.013]) in the year 2020 as compared with similar timeframes over the four prior years (Electronic Supplementary Material).

Analysis of the July 5-October 31, timeframe revealed a statistically significant decrease in Google search volume of 26 (i.e. tendonitis [ $-10.81 \%$; $p<0.001]$, fasciitis [-13.53\%; $p<0.001]$, bursitis $[-6.06 \% ; p: 0.001]$, spondylolisthesis [-8.34\%; $p$ : 0.008], herniated disc $[-5.71 \% ; p: 0.002]$, bulging disc $[-18.07 \% ; \quad p<0.001], \quad$ spinal stenosis [-10.32\%; $p<0.001]$, scoliosis $[-3.78 \%$; $p$ : 0.032], neck disc [-13.99\%; $p<0.001]$, de Quervain [-14.32\%; $p$ : 0.005], hip bursitis $[-7.94 \% ; p: 0.002]$, trochanteric bursitis [-11.83\%; $p$ : 0.007], iliopsoas syndrome $[-18.48 \% ; p$ : 0.039], knee swelling [-7.38\%; $p$ : 0.010], knee popping $[-12.78 \% ; p: 0.006]$, knee locking $[-16.59 \% ; p: 0.012]$, knee tendonitis [-25.91\%; $p<0.001]$, patellar tendonitis [-26.26\%; $p<0.001]$, prepatellar bursitis [-15.93\%; $p$ : 0.049], infrapatellar bursitis [-24.32\%; p: 0.009], Hoffa syn- drome $[-21.28 \% ; p: 0.001]$, meniscus tear $[-13.24 \% ; p<0.001]$, foot pain $[-6.41 \% ; \quad p<0.001]$, heel pain [-9.54\%; $p<0.001]$, plantar fasciitis $[-8.72 \% ; p<0.001]$ and bunion $[-4.84 \%$; $p$ : 0.015]) among 118 queries and a statistically significant increase in Google search volume of 21 queries (i.e. fatigue $[+12.37 \% ; p<0.001]$, joint pain $[+5.65 \% ; p: 0.002]$, muscle pain $[+5.60 \% ; p: 0.001]$, myalgia $[+136.70 \%$; $p<0.001], \quad$ spondylosis $[+7.29 \% ; p$ : $0.015]$, radiculopathy [+7.12\%; $p: 0.013]$, myelopathy $[+10.29 \%$; $p$ : 0.049], neck pain $[+5.28 \% ; p<0.001]$, neck strain [+32.17\%; $p<0.001]$, lower back strain [+21.79\%; $p<0.001]$, sciatica $[+4.41 \% ; p$ : $0.016]$, shoulder pain $[+7.05 \%$; $p<0.001]$, frozen shoulder $[+15.25 \% ; p<0.001]$, elbow pain $[+8.13 \% ; p<0.001]$, lateral epicondylitis $[+10.60 \% ; p: 0.011]$, wrist pain $[+5.03 \% ; p: 0.029]$, carpal tunnel $[+6.73 \% ; p<0.001]$, hand pain $[+4.46 \%$; $p: 0.024]$, finger pain $[+6.56 \% ; p$ : 0.012$]$, trigger finger $[+26.79 \% ; p<0.001]$ and Morton's neuroma [+19.04\%; $p$ : 0.020$]$ ), in the year 2020 as compared with similar timeframes over the four prior years (Electronic Supplementary Material).

\section{Discussion}

This study has demonstrated a statistically significant decrease in Google search volume of $60 \%$ of search queries in the early phase of pandemic, March 15July 4. However, in the July through October phase a statistically significant decrease was detected in only $22 \%$ of search queries; there was no difference for $60 \%$ of search queries between 2020 and 2016-2019 suggesting a return to their prior levels for the most of search queries that were decreased in the early phase. Interestingly, the search volume of $18 \%$ of search queries, namely, fatigue, joint pain, muscle pain, myalgia, spondylosis, radiculopathy, myelopathy, neck pain, neck strain, lower back strain, sciatica, shoulder pain, frozen shoulder, elbow pain, lateral epicondylitis, wrist pain, carpal tunnel, hand pain, finger pain, trigger finger, and Morton's neuroma, was significantly increased in July through October 2020 as compared with four prior years.
In the previous study analyzing Google search data, we found a significant decrease in public interest in the majority of inflammatory, autoimmune, and/or, vasculitis/connective tissue rheumatic diseases in the early phase of the pandemic [16]. In line with the previous study, the present results showed a general downward trend in internet searches for most of the soft tissue, regional, and degenerative musculoskeletal diseases in the initial pandemic period. It is possible that focusing on COVID-19 has led to a disregard of non-COVID-19 health conditions. This decreased interest may have individual and healthcare system implications. First, the outcomes and severity of musculoskeletal disorders might worsen. Second, after the resolution of the pandemic, a surge in demand for musculoskeletal care could overwhelm the healthcare system's capacity. Therefore, rheumatologists should address this decreased interest to minimize its potential adverse consequences.

In the initial period, internet searches for myalgia and toe swelling showed a significant increase. As myalgia is among the common symptoms of COVID-19 $[23,24]$, this observation was not unexpected. Furthermore, the increase in toe swelling was probably related to media coverage of chilblains associated with COVID-19, called as "COVID toe" [25-27]. In the second pandemic period, internet searches for toe swelling was not statistically significantly different compared to prior years, which might be due to that public accessed the information on this condition in the early pandemic and reduced their information intake after this period. Regardless, these findings indicate that the public has focused on COVID-19 and sought online information for COVID-19 symptoms in the early pandemic.

In July through October 2020, phase, internet searches for only $22 \%$ of all search queries remained low; however, the others were either not statistically significantly different or increased compared to prior years. This finding may reflect the recovery of public interest in musculoskeletal symptoms and disorders. Detailed inspection of this period showed an overall upward trend in symp- 
Hier steht eine Anzeige.

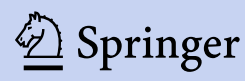


Z Rheumatol 2022 $\cdot 81: 247-252$ https://doi.org/10.1007/s00393-021-00989-2

c) Springer Medizin Verlag GmbH, ein Teil von Springer Nature 2021

S. Kardeş · A. Erdem · H. Gürdal

\section{Public interest in musculoskeletal symptoms and disorders during the COVID-19 pandemic. Infodemiology study}

\section{Abstract}

Objective. The goal was to assess public interest in a wide range of musculoskeletal symptoms and disorders during the coronavirus disease 2019 (COVID-19) pandemic.

Methods. We searched Google Trends for 118 search queries within the United States. We compared two timeframes of 2020 (March 15-July 4 and July 5-October 31) to similar timeframes over the four prior years (2016-2019).

Results. In the early pandemic, March 15-July 4 , a statistically significant decrease in relative search volume of the majority of queries (60\%) was detected, with a significant increase in only 2 queries (i.e. myalgia and toe swelling). In the phase July through
October, a statistically significant decrease was detected in only $22 \%$ of search queries; there was no difference for $60 \%$ of search queries between 2020 and 2016-2019 suggesting a return to their prior levels for most of search queries. Interestingly, the search volume of $18 \%$ of search queries (i.e. fatigue, joint pain, muscle pain, myalgia, spondylosis, radiculopathy, myelopathy, neck pain, neck strain, lower back strain, sciatica, shoulder pain, frozen shoulder, elbow pain, lateral epicondylitis, wrist pain, carpal tunnel, hand pain, finger pain, trigger finger, and Morton's neuroma) was significantly increased compared with the four prior years.

Conclusion. Public interest focused on COVID19 and sought online information for COVID-
19 symptoms in the early pandemic. In the period July through October, there was an upward trend in musculoskeletal symptoms and some colloquial terms/well-known musculoskeletal conditions coupled with a downward trend in general musculoskeletal disorder terms and certain specific diagnoses. This information may help rheumatologists understand public interest in musculoskeletal symptoms and disorders and address the needs of patients to mitigate the negative impact of the pandemic on outcomes.

\section{Keywords}

Google trends · Internet $\cdot$ Rheumatology .

Musculoskeletal diseases $\cdot$ Rheumatic

diseases $\cdot$ Soft tissue rheumatism

\section{Öffentliches Interesse an muskuloskeletalen Symptomen und Erkrankungen während der COVID-19- Pandemie. Infodemiologiestudie}

\section{Zusammenfassung}

Ziel. Das Ziel der Studie war, das öffentliche Interesse an einem breiten Spektrum von muskuloskeletalen Symptomen und Erkrankungen während der durch COVID19 (",oronavirus disease 2019") bedingten Pandemie zu untersuchen.

Methoden. Dazu durchsuchten die Autor(inn)en Google Trends in Bezug auf 118 Suchanfragen innerhalb der USA. Sie verglichen 2 Zeitfenster im Jahr 2020 (15. März bis 4. Juli und 5. Juli bis 31. Oktober) mit ähnlichen Zeitfenstern der 4 Jahre davor (2016-2019).

Ergebnisse. Zu Beginn der Pandemie, 13. März bis 4 . Juli, zeigte sich eine statistisch signifikante Abnahme des relativen Suchvolumens für die Mehrheit der Anfragen (60\%), ein signifikanter Anstieg jedoch nur bei 2 Anfragen (d. h. Myalgie und Zehenschwellung). In der Phase Juli bis Oktober fand sich eine statistisch signifikante Abnahme nur bei $22 \%$ der
Suchanfragen; es bestand kein Unterschied für $60 \%$ der Anfragen zwischen 2020 und 2016-2019, was auf ein Wiedererreichen des vorherigen Niveaus der meisten Suchanfragen schließen lässt. Interessant war, dass das Suchvolumen von $18 \%$ der Anfragen (d. h. zu Fatigue, Gelenkschmerzen, Muskelschmerzen, Myalgie, Spondylosis, Radikulopathie, Myelopathie, Nackenschmerzen, Nackenverspannung, Verspannung des unteren Rückens, Ischias, Schulterschmerzen, Schultersteife, Ellbogenschmerzen, laterale Epikondylitis, Handgelenkschmerzen, Karpaltunnel, Handschmerzen, Fingerschmerzen, schnellendem Finger und Morton-Neurom) im Vergleich zu den 4 vorangegangenen Jahren signifikant erhöht war.

Schlussfolgerung. In der Anfangszeit der Pandemie war das öffentliche Interesse auf COVID-19 fokussiert, und es wurde nach Online-Informationen über COVID-19-
Symptome gesucht. Während der Phase von Juli bis Oktober gab es einen Aufwärtstrend bei muskuloskeletalen Symptomen und einigen umgangssprachlichen Begriffen/wohl bekannten muskuloskeletalen Krankheiten, gekoppelt mit einem Abwärtstrend bei allgemeinen Begriffen zu muskuloskeletalen Erkrankungen und bestimmten spezifischen Diagnosen. Diese Informationen verhelfen möglicherweise den Rheumatologen dazu, das öffentliche Interesse an muskuloskeletalen Symptomen und Erkrankungen zu verstehen und auf die Bedürfnisse der Patienten einzugehen, um die negativen Auswirkungen der Pandemie auf den Krankheitsverlauf abzumildern.

\section{Schlüsselwörter}

Google Trends · Internet · Rheumatologie . Muskuloskeletale Erkrankungen · Rheumatische Erkrankungen · Weichteilrheumatismus toms (i.e. fatigue, joint pain, muscle pain, neck pain, shoulder pain, elbow pain, wrist pain, hand pain, and finger pain), and some colloquial terms/well-known conditions (i.e. myalgia, spondylosis, radiculopathy, myelopathy, neck strain, lower back strain, sciatica, frozen shoulder, lateral epicondylitis, carpal tunnel, and trigger finger). However, a decreased relative search volume for certain specific diagnoses (e.g. herniated disc, bulging disc, spinal stenosis, spondylolisthesis, neck disc, and de Quervain) was noted. It is possible that the reductions in outpatient visits [28-31] led to a decrease in the detection of these certain spe- cific diagnoses, which in turn lessened their internet searches. Considering the trends observed in this study (an upward trend in symptoms and some colloquial terms/well-known conditions coupled with a downward trend in general musculoskeletal disorder terms and certain specific diagnoses) and still on- 
going pandemic, rheumatologists should address the increased informational demand for musculoskeletal symptoms and develop effective strategies in delivering clinical care to minimize the potential detrimental impact of the pandemic on outcomes of patients with musculoskeletal disorders. Among these strategies, telerheumatology is gaining specific interest and being rapidly implemented in clinical practice during the pandemic [32-37].

\section{Limitations and strengths}

One limitation is that Google Trends only provides information on Google search engine data; in other words the internet searches performed through other engines (e.g. Bing, Yahoo!, DuckDuckGo) were not included. However, since about $90 \%$ of internet searches are performed on Google [38], its data probably represent all online search queries. Furthermore, Google Trends does not provide demographic characteristics of users; therefore interest cannot be assessed by dividing into subcategories based on age or sex. Hence, the trends observed in our study should be interpreted as an interest of the general public. The strengths of the present study involve an exhaustive list of search terms representing a wide spectrum of musculoskeletal symptoms/disorders; and a long period of investigation that allowed assessment of interest in both initial and short-term stages of the pandemic.

\section{Conclusion}

Public interest has focused on COVID19 and sought online information for COVID-19 symptoms in the early pandemic. In the July through October period, there was an upward trend in musculoskeletal symptoms and some colloquial terms/well-known musculoskeletal conditions and a downward trend in general musculoskeletal disorders-terms and certain specific diagnosis. This information may help rheumatologists understand public interest in musculoskeletal symptoms and disorders and address the needs of patients to mitigate the negative impact of the pandemic on outcomes.

\section{Corresponding address}

\section{Sinan Kardeş, MD}

Department of Medical Ecology and

Hydroclimatology, Istanbul Faculty of Medicine, Istanbul University

Topkapı, Turgut Özal Millet Cd,

34093 Fatih/Istanbul, Turkey

sinan.kardes@istanbul.edu.tr

\section{Declarations}

Conflict of interest. S. Kardeş, A. Erdem and H. Gürdal declare that they have no competing interests.

For this article no studies/interventions with human participants or animals were performed by any of the authors. All studies mentioned were in accordance with the ethical standards indicated in each case. This study was performed in accordance with national legal requirements.

\section{References}

1. GBD 2017 Disease and Injury Incidence and Prevalence Collaborators (2018) Global, regional, and national incidence, prevalence, and years lived with disability for 354 diseases and injuries for 195 countries and territories, 1990-2017: a systematic analysis for the global burden of disease study 2017. Lancet 392:1789-1858. https://doi.org/10.1016/S0140-6736(18)32279-7

2. Jin Z, Wang D, Zhang H, Liang J, Feng X, Zhao J, Sun $L$ (2020) Incidence trend of five common musculoskeletal disorders from 1990 to 2017 at the global, regional and national level: results from the global burden of disease study 2017. Ann Rheum Dis 79:1014-1022. https://doi.org/10. 1136/annrheumdis-2020-217050

3. Safiri S, Kolahi AA, Cross M, Hill C, Smith E, Carson-Chahhoud K, Mansournia MA, AlmasiHashiani A, Ashrafi-Asgarabad A, Kaufman J, Sepidarkish M, Shakouri SK, Hoy D, Woolf AD, March L, Collins G, Buchbinder R (2020) Prevalence, deaths and disability adjusted life years (DALYs) due to musculoskeletal disorders for 195 countries and territories 1990-2017. Arthritis Rheumatol. https://doi.org/10.1002/art.41571

4. Bernetti A, Mangone M, Alviti F, Paolucci T, Attanasi C, Murgia M, Di Sante L, Agostini F Vitale M, Paoloni M (2020) Spa therapy and rehabilitation of musculoskeletal pathologies: a proposal for best practice in Italy. Int J Biometeorol 64:905-914. https://doi.org/10. 1007/s00484-019-01731-z

5. Masiero S, Litwocenko S, Agostini F (2020) Rehabilitation in an Italian thermal setting: a new therapeutic strategy for patients with musculoskeletal disability-the results of an Italian survey. Int J Biometeorol 64:951-954. https://doi. org/10.1007/s00484-019-01765-3

6. Rapolienè $L$, Razbadauskas A, Mockevičienè $D$, Varžaitytė L, Skarbalienè A (2020) Balneotherapy for musculoskeletal pain: does the mineral content matter? Int J Biometeorol 64:965-979. https://doi. org/10.1007/s00484-019-01800-3

7. Lewis R, Gómez Álvarez CB, Rayman M, LanhamNew S, Woolf A, Mobasheri A (2019) Strategies for optimising musculoskeletal health in the 21st century. BMC Musculoskelet Disord 20:164. https://doi.org/10.1186/s12891-019-2510-7

8. Martinez-Arroyo G, Ramos-GomezS, Rojero-GilEK, Rojas-Gongora JA, Barajas-Ochoa A, BustamanteMontes LP, Yañez J, Ramos-Remus C (2019) Potential uses of an infodemiology approach for health-care services for rheumatology. Clin Rheumatol 38:869-876. https://doi.org/10.1007/ s10067-018-4364-z

9. Dey M, Zhao SS (2020) Google search data as a novel adjunct to patient and public involvement in rheumatology research. Rheumatol Int. https:// doi.org/10.1007/s00296-020-04723-0

10. Jellison SS, Bibens M, Checketts J, Vassar M (2018) Using Google trends to assess global publicinterest in osteoarthritis. Rheumatol Int 38:2133-2136. https://doi.org/10.1007/s00296-018-4158-2

11. Bragazzi NL, Amital $H$, Adawi M, Brigo F, Watad $S$, Aljadeff G, Amital D, Watad A (2017) What do people search online concerning the "elusive" fibromyalgia? Insights from a qualitative and quantitative analysis of Google trends. Clin Rheumatol 36:1873-1878. https://doi.org/10. 1007/s10067-017-3665-y

12. Kardeş $S$ (2019) Seasonal variation in the internet searches for gout: an ecological study. Clin Rheumatol 38:769-775. https://doi.org/10.1007/ s10067-018-4345-2

13. Mei YJ, Mao YM, Cao F, Wang T, Li ZJ (2020) Using internet search data to explore the global public concerns in ankylosing spondylitis. Postgrad Med J. https://doi.org/10.1136/postgradmedj2019-137407

14. Wu GC, Tao SS, Zhao CN, Mao YM, Wu Q, Dan YL, Pan HF (2019) Leveraging Google trends to investigate the global public interest in rheumatoid arthritis. Rheumatol Int 39:1439-1444. https:// doi.org/10.1007/s00296-019-04297-6

15. Kardeş S, Kuzu AS, Pakhchanian H, Raiker R, Karagülle M (2020) Population-level interest in anti-rheumatic drugs in the COVID-19 era: insights from Google trends. Clin Rheumatol. https://doi. org/10.1007/s10067-020-05490-W

16. Kardeş $S$, Kuzu AS, Raiker R, Pakhchanian $H$, Karagülle M (2020) Public interest in rheumatic diseases and rheumatologist in the United States during the COVID-19 pandemic: evidence from Google trends. Rheumatol Int 41:329-334. https:// doi.org/10.1007/s00296-020-04728-9

17. Kardeş $S$ (2019) Seasonal variation in the internet searches for psoriasis. Arch Dermatol Res 311:461-467. https://doi.org/10.1007/s00403019-01921-0

18. Kardeş S, Kardeş E (2019) Seasonality of bruxism: evidence from Google trends. Sleep Breath 23:695-701. https://doi.org/10.1007/s11325019-01787-6

19. Kardeş S (2021) Public interest in spa therapy during the COVID-19 pandemic: analysis of Google trends data among Turkey. Int J Biometeorol. https://doi.org/10.1007/s00484-021-02077-1

20. Mavragani A, Ochoa G (2019) Google trends in infodemiology and Infoveillance: methodology framework. JMIR Public Health Surveill 5:e13439. https://doi.org/10.2196/13439

21. Esen-Salman K, Akın-Çakıcı Ö, Kardeş S, Salman A (2021) Public interest in dermatologic symptoms, conditions, treatments, and procedures during the COVID-19 pandemic: insights from Google trends. Dermatol Ther. https://doi.org/10.1111/ dth. 14895

22. Misra DP, Zimba O, Gasparyan AY (2021) Statistical data presentation: a primer for rheumatology 
researchers. Rheumatol Int 41:43-55. https://doi. org/10.1007/s00296-020-04740-Z

23. Misra DP, Agarwal V, Gasparyan AY, Zimba O (2020) Rheumatologists' perspective on coronavirus disease 19 (COVID-19) and potential therapeutic targets. Clin Rheumatol 39:2055-2062. https:// doi.org/10.1007/s10067-020-05073-9

24. Ciaffi J, Meliconi R, Ruscitti P, Berardicurti O, Giacomelli R, Ursini F (2020) Rheumatic manifestations of COVID-19: a systematic review and metaanalysis. BMC Rheumatol 4:65. https://doi.org/10. 1186/s41927-020-00165-0

25. Kabeerdoss J, Pilania RK, Karkhele R, Kumar TS, Danda D, Singh S (2020) Severe COVID-19, multisystem inflammatory syndrome in children, and Kawasaki disease: immunological mechanisms, clinical manifestations and management. Rheumatol Int. https://doi.org/10.1007/s00296020-04749-4

26. ShahS, Danda D, KavadichandaC, Das S, Adarsh MB, Negi VS (2020) Autoimmune and rheumatic musculoskeletal diseases as a consequence of SARS-CoV-2 infection and its treatment. Rheumatol Int 40:1539-1554. https://doi.org/10. 1007/s00296-020-04639-9

27. Rabin RC (2020) What is 'Covid toe'? Maybe a strange sign of Coronavirus infection. https://www.nytimes.com/2020/05/01/health/ coronavirus-covid-toe.html/. Accessed $29 \mathrm{Nov}$ 2020

28. Ziadé N, Hmamouchi I, el Kibbi L, Abdulateef $\mathrm{N}$, Halabi $\mathrm{H}$, Abutiban F, Hamdi W, el Rakawi M, Eissa M, Masri B (2020) The impact of COVID-19 pandemic on rheumatology practice: a crosssectional multinational study. Clin Rheumatol
39:3205-3213. https://doi.org/10.1007/s10067020-05428-2

29. Freudenberg S, Vossen D (2020) Impact of COVID19 on rheumatological care: a national survey in April 2020. Z Rheumatol 79(6):584-589. https:// doi.org/10.1007/s00393-020-00833-Z

30. Yağcı İ, Sarıkaya S, Ayhan FF, Bahsi A, Bilir Kaya B, Erhan B, Dündar Ahi E, Okan S, Özkan Y, Korkmaz MD, Yakşi E, Demirbağ Kabayel D, Özdemir H, Kayalar G, Çelik C, Kesiktaş FN, Çağlar Yagcı H, Altan L (2020) The effects of COVID-19 on physical medicine and rehabilitation in Turkey in the first month of pandemic. Turk J Phys Med Rehabil 66:244-251. https://doi.org/10.5606/ tftrd.2020.6800

31. Gheita TA, Salem MN, Eesa NN, Khalil NM, Gamal NM, Noor RA, Moshrif AH, Shereef RE, Ismail F, Noshy N, Fawzy RM, Elshebini E, Khalifa I, Saadany HE, Tharwat S, El-Najjar A, Fattah YA, Sallam R, El-Bahnasawy AS, Gharbia O, Hassan E, ElShanawany A, Mohamed EF, Senara S, Ismail M, Nasef SI, Abdalla AM, Elessawi D, Fawzy SM, Alfadl EA, Khalifa A, Abaza NM, ECRCOVID19-Study Group (2020) Rheumatologists' practice during the Coronavirus disease 2019 (COVID-19) pandemic: a survey in Egypt. Rheumatol Int 40:1599-1611. https://doi.org/10.1007/s00296-020-04655-9

32. Naveen R, Sundaram TG, Agarwal V, Gupta L (2020) Teleconsultation experience with the idiopathic inflammatory myopathies: a prospective observational cohort study during the COVID-19 pandemic. Rheumatol Int. https://doi.org/10. 1007/s00296-020-04737-8

33. Krusche $M$, Mühlensiepen $F$, Aries $P$, Welcker $M$, Knitza J (2020) Telemedicine in rheumatology.
Z Rheumatol 79(9):883-892. https://doi.org/10 1007/s00393-020-00912-1

34. Patel V, Stewart D, Horstman MJ (2020) E-consults: an effective way to decrease clinic wait times in rheumatology. BMC Rheumatol 4:54. https://doi. org/10.1186/s41927-020-00152-5

35. Shenoy P, Ahmed S, Paul A, Skaria TG, Joby J, Alias B (2020) Switching to teleconsultation for rheumatology in the wake of the COVID-19 pandemic: feasibility and patient response in India. Clin Rheumatol 39:2757-2762. https://doi.org/10. 1007/s10067-020-05200-6

36. Kavadichanda C, Shah S, Daber A, Bairwa D, Mathew A, Dunga S, Das AC, Gopal A, RaviK, Kar SS, Negi VS (2020) Tele-rheumatology for overcoming socioeconomic barriers to healthcare in resource constrained settings: lessons from COVID-19 pandemic. Rheumatology (Oxford). https://doi. org/10.1093/rheumatology/keaa791

37. Aries P, Welcker M, Callhoff J, Chehab G, Krusche M, Schneider M, Specker C, Richter JG (2020) Statement of the German society for rheumatology (DGrh) on the use of video consultations in rheumatology. Z Rheumatol 79:1078-1085. https://doi.org/10.1007/s00393-020-00932-x

38. Statcounter Statcounter. https://gs.statcounter. com/search-engine-market-share/. Accessed 29 Nov 2020.

\section{Hier steht eine Anzeige.}

\section{Springer}

